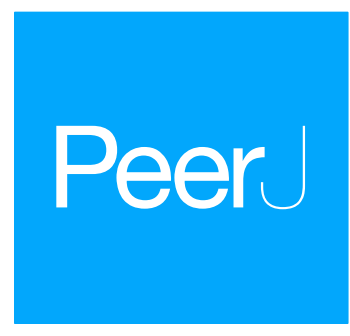

Submitted 2 March 2018 Accepted 10 April 2018 Published 25 April 2018

Corresponding author Nilson A. Assuncao, nilson.assuncao@gmail.com, nilson.assuncao@unifesp.br

Academic editor

Vladimir Uversky

Additional Information and Declarations can be found on page 18

DOI 10.7717/peerj.4688

Copyright

2018 Jedlicka et al.

Distributed under

Creative Commons CC-BY 4.0

OPEN ACCESS

\section{Increased chemical acetylation of peptides and proteins in rats after daily ingestion of diacetyl analyzed by Nano-LC-MS/MS}

\author{
Leticia Dias Lima Jedlicka ${ }^{1,2}$, Sheila Barreto Guterres ${ }^{1,3}$, Aleksandro Martins \\ Balbino $^{1}$, Giuseppe Bruno Neto ${ }^{1}$, Richardt Gama Landgraf ${ }^{1}$, Liliam Fernandes ${ }^{1}$, \\ Emanuel Carrilho $^{4}$, Etelvino José Henriques Bechara ${ }^{1,5}$ and Nilson A. Assuncao ${ }^{1}$ \\ Institute of Environmental, Chemical and Pharmaceutical Sciences, Universidade Federal de São Paulo, \\ Diadema, SP, Brazil \\ ${ }^{2}$ Institute of Studies in Health and Biological, Collective Health, Universidade Federal do Sul e Sudeste do Pará, \\ Maraba, PA, Brazil \\ ${ }^{3}$ Department of Chemistry, Fundação Universidade Federal de Rondônia, Porto Velho, RO, Brazil \\ ${ }^{4}$ São Carlos Institute of Chemistry, Universidade de São Paulo, São Carlos, SP, Brazil \\ ${ }^{5}$ Department of Fundamental Chemistry, Institute of Chemistry, Universidade de São Paulo, \\ São Paulo, SP, Brazil
}

\section{ABSTRACT}

Background. Acetylation alters several protein properties including molecular weight, stability, enzymatic activity, protein-protein interactions, and other biological functions. Our previous findings demonstrating that diacetyl/peroxynitrite can acetylate L-lysine, L-histidine, and albumin in vitro led us to investigate whether diacetyl-treated rats suffer protein acetylation as well.

Methods. Wistar rats were administered diacetyl daily for four weeks, after which they were sacrificed, and their lung proteins were extracted to be analysed by Nano-LCMS/MS (Q-TOF). A C18 reversed-phase column and gradient elution with formic acid/acetonitrile solutions from 2 to $50 \%$ over $150 \mathrm{~min}$ were used to separate the proteins. Protein detection was performed using a microTOF-Q II (QTOF) equipped with captive source and an electrospray-ionization source. The data from mass spectrometry were processed using a Compass 1.7 and analyzed using Protein Scape, software that uses Mascot algorithms to perform protein searches.

Results. A set of 3,162 acetylated peptides derived from 351 acetylated proteins in the diacetyl-treated group was identified. Among them, 23 targeted proteins were significantly more acetylated in the diacetyl-treated group than in the PBS control. Protein acetylation of the group treated with $540 \mathrm{mg} / \mathrm{kg} /$ day of diacetyl was corroborated by Western blotting analysis.

Conclusions. These data support our hypothesis that diacetyl exposure in animals may lead to the generation of acetyl radicals, compounds that attach to proteins, affecting their functions and triggering adverse health problems.

Subjects Biochemistry, Toxicology

Keywords Radical acetylation, Diacetyl, Food additive, Lung diseases, Proteomics. 


\section{INTRODUCTION}

Diacetyl is a flavoring commonly used in foodstuffs, as it lends a buttery flavor to products such as popcorn, coffee blends, cakes, cookies, wines and other goods (McCoy et al., 2017; Shibamoto, 2014; Ryan et al., 2014; Papetti, Mascherpa \& Gazzani, 2014; Park, Gilbert \& Whittaker, 2018; More, Raza \& Vince, 2012). It is a volatile $\alpha$-dicarbonyl and a highly electrophilic compound (Ryan et al., 2014) approved worldwide for use by food industries, despite ongoing health concerns dating back to 1986 (NIOSH, 1986), when the first cases of bronquiolitis obliterans involving diacetyl emerged (Park, Gilbert \& Whittaker, 2018; Kreiss, 2014; Kanwal et al., 2011).

Recently, we reported that the reaction of peroxynitrite with $\alpha$-dicarbonyls, namely diacetyl and methylglyoxal, in aerated phosphate buffer $\mathrm{pH} 7.4$ results in the acetylation of free amino acids, peptides and proteins added to the reaction mixture (Alves et al., 2013; Massari et al., 2010; Massari et al., 2011; Tokikawa et al., 2014). This reaction is initiated by nucleophilic addition of peroxynitrite to the carbonyl group of the $\alpha$-dicarbonyl compound yielding a peroxynitroso adduct, whose homolysis yields acetyl radicals. Dissolved molecular oxygen adds to the radical to ultimately produce acetate from diacetyl or acetate and formate from methylglyoxal (Massari et al., 2010; Massari et al., 2011). Formyl radical intermediate generated by methylglyoxal/peroxynitrite was shown to add to the $\alpha$-amino group of L-lysine-containing synthesized tetrapeptides (Tokikawa et al., 2014). On the other hand, diacetyl/peroxynitrite-generated acetyl radicals have proven been proven to attack both the $\alpha$ - and $\varepsilon$-amino groups of free and blocked L-Lys, L-Lys-containing peptides and serum albumin (Alves et al., 2013). These findings have raised the hypothesis that radical acetylation of proteins contributes to transacetylase-promoted, post-translational protein modifications at sites where both methylglyoxal or diacetyl and peroxynitrite are present (Alves et al., 2013; Massari et al., 2010; Massari et al., 2011; Tokikawa et al., 2014). From these facts, the competition of chemical (induced by diacetyl) and enzymatic (occurring naturally in organisms) acetylation can be inferred, with the former process contributing to the increase of total protein acetylation.

Another source of acetylation in vivo is found through the action of acetyltransferases. These enzymes reversibly catalyze the transfer of the acetyl group from acetyl-CoA to the $\varepsilon$-amino group of protein lysine residues (Drazic et al., 2016), a process promoted by lysine acetyltransferase and lysine deacetylase (Meng et al., 2018; Arif, Selvi $\&$ Kundu, 2010; Iyer, Fairlie \& Brown, 2012) at the $\mathrm{N}$-terminus during the synthesis of proteins. Protein acetylation is highly conserved in eukaryotes and prokaryotes than phosphorylation, but it is less common than phosphorylation and ubiquitination (McEwan \& Dikic, 2011). Acetylation can reportedly alter the protein function, size, enzymatic activity, stability, protein-protein interactions and other protein properties. When acetyltransferase is deregulated, and lysine acetylation is increased, modifications may occur in genes and in the regulatory machinery, resulting in the manifestation of tumours in cells (Drazic et al., 2016). On the other hand, ATP-dependent acetylation has recently been reported to play a

role in many cellular processes such as catalytic activity, immune responses and metabolic processes, including the generation of precursors of "energy-rich" metabolites such as 
acetylphosphate (acP). AcP-dependent acetylation tends to govern the translation of nucleotides, purine and pyrimidine metabolism and degradation of RNA (Kuhn et al., 2014).

In this work, we use proteomic and western blotting techniques to investigate if diacetyl is also capable of leading to increases in vivo protein acetylation. Based on our findings, we support the hypothesis that diacetyl exposure in animals may lead to increases in protein acetylation, which may affect protein functions and trigger adverse health problems.

\section{METHODS}

\section{Animal treatment}

All animals were fed ad libitum and kept in a cabinet at 50-70\% humidity, at a temperature of $19-26^{\circ} \mathrm{C}$ in a cycle of $12 \mathrm{~h} \mathrm{light} / 12 \mathrm{~h}$ dark. This study adheres to the guidelines established by the Brazilian College of Animal Experimentation (COBEA) and was approved by the Ethical Committee of the School Medicine of the Federal University of São Paulo (UNIFESP, protocol no. 1949-11).

Eight-to-twelve-week-old male Wistar rats (250-300 g) were divided into two groups (6 animals each). The control group received phosphate-buffered saline (PBS), while the treated group received $540 \mathrm{mg} / \mathrm{kg} /$ day of diacetyl (Cat B8530-7; Sigma Aldrich, St. Louis, MO, USA) dissolved in PBS Both groups were dosed using gavage. The concentration of $540 \mathrm{mg} / \mathrm{Kg} /$ day of 2,3-butanedione and the treatment period of four weeks was based on the experiment conducted by Colley and Cols (Colley et al., 1969).

After four weeks of treatment, the animals were anesthetized with ketamine and xylazine (Sigma Aldrich, St. Louis, MO, USA) and sacrificed. The lung tissue was collected and immediately frozen in liquid nitrogen and stored at $-80^{\circ} \mathrm{C}$.

\section{Preparation of lung extracts Tissue preparation}

Frozen lungs were ground into a fine powder in liquid nitrogen using a mortar and pestle. The homogenization process was used to avoid the activation of proteases and prevents protein degradation. The sample was lyophilized prior to analysis in order to remove residual water and stabilize the sample for handling at room temperature, thereby facilitating the weighing process and preparation of the sample.

\section{Protein extraction optimization}

Due to the wide range of proteins and interfering substances in the final extracts, the samples were obtained in the following three steps prior to proteomics analysis: tissue disaggregation and cell homogenization; protein extraction from the biological matrix; and protein precipitation and solubilisation in a urea buffer.

Three methods of protein extraction were tested to quantify the amount of protein in the lysates before and after precipitation (Table 1). Thirteen milligrams of lyophilized lung suspended in one $\mathrm{mL}$ of extraction buffer were used.

The lung powder was suspended and shaken for $1 \mathrm{~h}$ at $4{ }^{\circ} \mathrm{C}$. After centrifugation ( $10 \mathrm{~min}$, $\left.5,000 \times \mathrm{RPM}, 4^{\circ} \mathrm{C}\right), 200 \mu \mathrm{L}$ of the supernatant was mixed with $800 \mu \mathrm{L}$ of DTT solution in cold acetone $(2 \mathrm{mg} / \mathrm{mL})$ and incubated overnight at $-20^{\circ} \mathrm{C}$. Afterwards, the samples were 


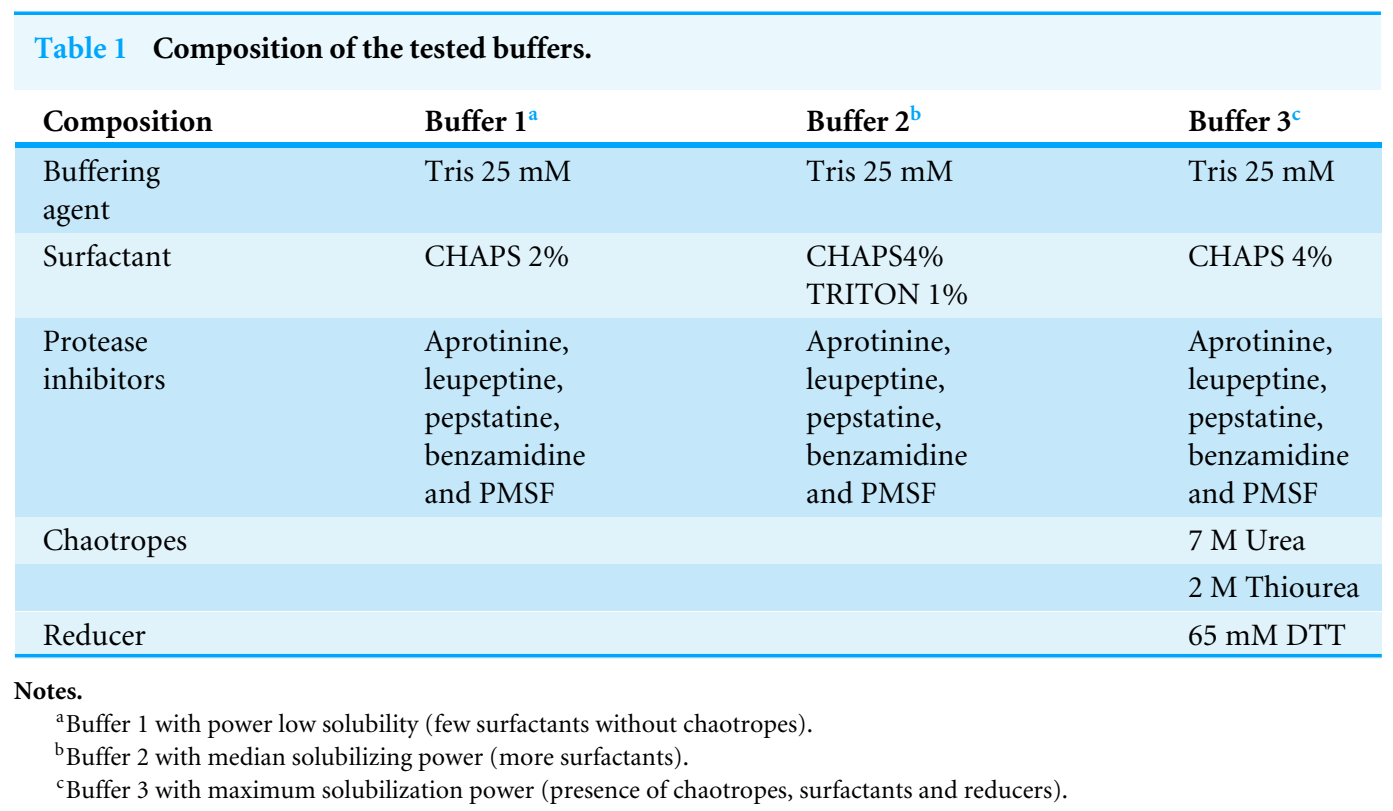

centrifuged (10 min, $16,000 \times \mathrm{RPM}, 4^{\circ} \mathrm{C}$ ), and the sediments were washed four times with the DTT solution, dried in vacuum and solubilized in urea buffer $\left(7 \mathrm{~mol} \mathrm{~L}^{-1}\right.$ urea, $2 \mathrm{~mol} \mathrm{~L}^{-1}$ thiourea, $4 \%$ CHAPS). The total protein concentration was determined by the Bradford method (Bradford, 1976).

\section{Tryptic digestion}

Prior to tryptic digestion, polypropylene microtubes were individually filled with an extract aliquot containing $250 \mu \mathrm{g}$ of the lung protein. The samples were reduced with Dithiothreitol (DTT) solution until achieving a final concentration of $5 \mathrm{mmol} \mathrm{L}{ }^{-1}$, and they were then incubated for $25 \mathrm{~min}$ at $56^{\circ} \mathrm{C}$. To achieve alkylation in the samples, iodoacetoamide (IAA) was added until reaching a final concentration of $14 \mathrm{mmol} \mathrm{L}^{-1}$. The samples were then incubated for $30 \mathrm{~min}$ at room temperature and protected from light. Afterward, they were diluted until the concentration of urea was reduced to $1,600 \mathrm{mmol} \mathrm{L}^{-1}$, and a $\mathrm{CaCl}_{2}$ solution was added until reaching a final concentration of $1 \mathrm{mmol} \mathrm{L}^{-1}$ of $\mathrm{CaCl}_{2}$.

The enzymes trypsin and LysC endoproinase were added in the ratio of 1:50 of (enzyme: substrate). The samples were incubated for $18 \mathrm{~h}$ at $37^{\circ} \mathrm{C}$. The enzyme reaction was stopped by adding TFA (trifluoroacetic acid) at the final concentration of $0.4 \%$. The samples were centrifuged at 2,500 $\mathrm{rpm}$ for $10 \mathrm{~min}$ at room temperature, and the pellet was discarded. The sample was evaporated until the volume was reduced to approximately $50 \mu \mathrm{l}$ using a vacuum concentrator (Speed Vacuum; Thermo Fisher Scientific, Waltham, MA, USA). Finally, $50 \mu \mathrm{l}$ of $0.5 \%$ trifluoroacetic acid (TFA) were added thereto. Detergents were removed from the sample using a Pierce detergent removal spin column (\# 87776; Pierce Biotechnology/Thermo Fisher Scientific, Waltham, MA, USA), which was used according to the manufacturer's specifications; the samples were filtered through a $22 \mu \mathrm{m}$ PVDF syringe filter stocked at $4{ }^{\circ} \mathrm{C}$ for mass spectrometry analysis. 


\section{NanoLC-ESI/MS/MS analyses}

In this study, on average six biological replicates and two replicate techniques were used. However, due to technical problems, we used 11 replicates of the control group and 10 replicates of the group treated with $540 \mathrm{mg} / \mathrm{kg} /$ day of diacetyl. Each trypsinized sample was dissolved with $100 \mu \mathrm{L}$ of a mixture of water/acetonitrile/TFA (949:50:1 v/v). All analyses were performed using a Nano-UHPLC Advance (Bruker Daltonics, Bremen, Germany) equipped with a pump, an auto sampler, and a thermostatically controlled column compartment. A C18 reversed-phase column (Magic C18 AQ, P/N: CP3/61271/00; Michrom, Boise, ID, USA), particle size $3 \mu \mathrm{m}$, internal diameter $0.1 \mathrm{~mm}$, length $100 \mathrm{~mm}$ was used. The column temperature was kept at $40{ }^{\circ} \mathrm{C}$. Samples were separated using a gradient mobile phase consisting of (A) formic acid/ACN/ $\mathrm{H}_{2} \mathrm{O}(1: 20: 979)$ and (B) formic acid/ACN/ $\mathrm{H}_{2} \mathrm{O}(1: 950: 50)$ in a gradient elution from 2 to $50 \%$ over $150 \mathrm{~min}$, as a graph in SM1. The flow rate was set at $0.500 \mu \mathrm{L} / \mathrm{min}$, and the injection volume was $5 \mu \mathrm{L}$. Detections were performed using a micrOTOF-Q II (Bruker Daltonics, Billerica, MA, USA), an accurate mass instrument equipped with captive source (Bruker Daltonics, Billerica, MA, USA) and an electrospray-ionization source (ESI). The mass spectrometer was running in positive mode, with the desolvation temperature at $180{ }^{\circ} \mathrm{C}$ and the nebulizer set at 500 $\mathrm{V}$ and 0.4 bars. All the operations, acquisition, and analysis of data were controlled by Hystar software version 1.7 (Bruker Daltonics, Billerica, MA, USA). For MS/MS analyses, five precursor ions were automatically selected to undergo collision and fragmentation with argon gas ( $\geq 2 \mathrm{~L} / \mathrm{min}$ ). Mass spectra were collected between 50 to $3,000 \mathrm{~m} / \mathrm{z}$, and calibration was performed at the beginning of every day using the Tune-Mix ESI-G (Agilent Technologies, Santa Clara, CA, USA). The collision energy was $12 \mathrm{eV}$, collision RF $600 \mathrm{Vpp}$, transfer time $140 \mu \mathrm{s}$, and pre-pulse storage $14 \mu \mathrm{s}$. MS/MS parameters were three precursor ions, absolute threshold 2,000 cts, smart exclusion 5×, excluded after three spectra, and released after $1 \mathrm{~min}$. The tune parameters were Funnel 1RF 300 Vpp, Funnel 2 RF 400 $\mathrm{Vpp}$, hexapole RF $400 \mathrm{Vpp}$, quadrupole ion energy $6.0 \mathrm{eV}$, and low mass $300 \mathrm{~m} / \mathrm{z}$. The TOF (time of flight) conditions included the following: repetition rate $5 \mathrm{kHz}$, sample rate $2 \mathrm{Ghz}$, flight tube $8,600 \mathrm{~V}$, reflector $1,700 \mathrm{~V}$, detector source $1,700 \mathrm{~V}$, and detector TOF $2140 \mathrm{~V}$. Argon was used as a collision gas at a pressure of $2 \times 10^{-6} \mathrm{mbar}$, and the collision energy values were $10-200 \mathrm{eV}$.

\section{Bioinformatic analysis Data deconvolution and database search}

Data from mass spectrometry were processed using a Compass 1.7 for OTOF (Bruker Daltonics, Billerica, MA, USA) and deconvoluted to generate a file compatible with Mascot. This file was analyzed using Protein Scape (Bruker Daltonics, Billerica, MA, USA), a program that uses Mascot algorithms to perform the search. The database used was Swissprot, an annotated protein sequence database. The taxonomy was rattus, and the enzyme was trypsin with two missed cleavages. The fixed modification was carbamidomethylation, and the variable modifications were oxidation of methionine and acetylation of lysine and arginine. Mass tolerance modification was $150 \mathrm{ppm}$ to $1 \mathrm{Da}$. Mascot analysis of all proteins $(p<0.05)$ used a minimum score of 35 . 


\section{Protein network analysis}

The protein-protein interaction analysis was performed using Cytoscape 3.3.0 software (http://www.cytoscape.org/) (Shannon et al., 2003), and the protein interaction network was obtained from the STRING 8.2 database (http://string-db.org/) (Szklarczyk et al., 2011). STRING 8.2 uses the metric of "confidence score" to define the confidence of the interactions. We selected only the interactions with proteins identified in our analyses.

\section{Orthologs analysis}

Orthologs were subjected to Gene Ontology (GO) term analysis based on PANTHER classification online tools (http://pantherdb.org/). To determine the biochemical functions of acetylated proteins detected in the lungs of the group treated with diacetyl, GO was performed using IDs with the Rattus norvegicus genome found in the Uniprot database. This particular database was chosen as the reference database for the output report of biologicals process, proteins class, cellular components, pathways and molecular functions (Mi et al., 2013). These analyses were performed to acquire insights of the acetylation involved in the functions and pathways of proteins.

\section{Analysis of sequence model around acetylated lysine}

The software motif- $x$ was employed to determine specific sequences of amino acid (15 amino acids upstream and downstream of the acetylation site) in all protein sequences acquired from NanoLC-MS/MS analysis. The entire database (IPI Rat Proteome) was used as a background database parameter, and the significance was 0.000001 (Chou \& Schwartz, 2011; Schwartz \& Gygi, 2005).

\section{Western blotting}

Samples containing $25 \mu \mathrm{g}$ of proteins from lung homogenate were subjected to $12 \%$ SDS-PAGE electrophoresis and electroblotted onto a nitrocellulose membrane (Millipore, USA). Following the blocking and washing steps, the membranes were incubated with the primary Acetylated-Lysine antibody (Cell Signalling, Danvers, MA, USA) and anti-rabbit IgG HRP-linked (Cell Signalling, Danvers, MA, USA) as a secondary antibody. The membranes were then detected using a chemiluminescence kit "Pierce ECL Plus Western Blotting Substrate" (Thermo Scientific, Waltham, MA, USA) and chemiluminescence software (GeneGnome System/Gene Tools Software; Syngene, Cambridge, UK).

\section{RESULTS}

\section{Protein extraction optimization}

We performed three different protein extraction methods to determine which one yielded the most consistent results when reproduced. That method was then adopted, allowing for increased accuracy in the estimation of protein amounts from the lysate extracts. Figure 1 shows a comparison of the amount of proteins between lung lysate and the solution of precipitate lung proteins resuspended. 


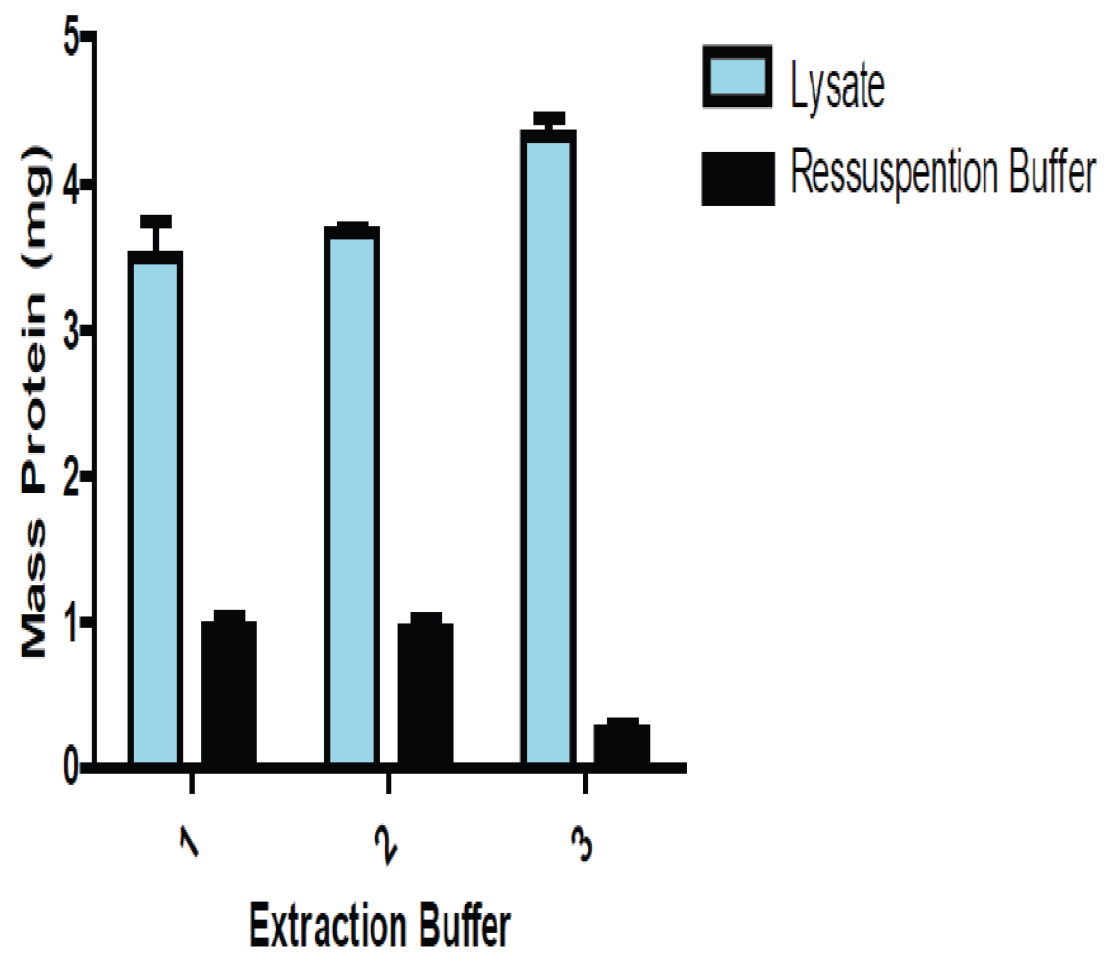

Figure 1 Comparison of the amount of total protein present in the lysate and the resolubilizated proteins (precipitate proteins resuspended) using lung tissue.

Full-size DOI: 10.7717/peerj.4688/fig-1

\section{MS/MS analyses of rat lung proteins}

In this work, qualitative proteomic analysis was used, specifically the bottom up technique. The lung extracts were analyzed by NanoLC-MS/MS, and significant differences were shown among the protein profiles in the control and diacetyl-treated groups. Acetylation was set in the search engine as a variable modification, and overall, the analyses showed 10,302 peptides identified as belonging to 603 proteins in lung tissue. A set of 327 acetylated proteins in the control group and 351 proteins in the group treated with $540 \mathrm{mg} / \mathrm{kg} / \mathrm{day}$ of diacetyl were detected. This increase in acetylation can occur either enzymatically or chemically, a phenomenon presently demonstrated in this work.

In this experiment, we identified 93 proteins which were common between the control group and the 2,3-butanedione treated group. After this identification, we verified the peptides present in these 93 proteins, the peptides common among the groups and the incidence of acetylation in these peptides. This peptide analysis was performed to ensure that the acetylations found were due to the ingestion of 2,3-butanedione. We only validated the acetylations that were exclusively present in the treated group or that were expressed in a larger number in the treated group compared to the control group. After this analysis of the acetylated peptides, we selected 23 proteins, to which these acetylated peptides belong, and named them as 'target proteins'.

Analysis of proteins and peptides revealed that acetylation is more abundant in the group treated with 2,3-butanedione than in the control group. The proteins that exhibited this 


\begin{tabular}{|c|c|c|c|c|c|c|c|}
\hline Protein I.D. & $\begin{array}{l}\text { Gene } \\
\text { I.D. }\end{array}$ & $\begin{array}{l}\text { Meta score } \\
\text { control }\end{array}$ & $\begin{array}{l}\text { Meta score } \\
\text { treated }\end{array}$ & $\begin{array}{l}\text { Peptides } \\
\text { control }\end{array}$ & $\begin{array}{l}\text { Peptides } \\
\text { treated }\end{array}$ & $\begin{array}{l}{ }^{\star} \mathrm{SC}[\%] \\
\text { control }\end{array}$ & $\begin{array}{l}{ }^{\star} \mathrm{SC}[\%] \\
\text { treated }\end{array}$ \\
\hline AL1A1_RAT & AL1A1 & 269.1 & 253.5 & 11 & 9 & 37.1 & 31.7 \\
\hline ANXA2_RAT & ANXA2 & 539.6 & 284.6 & 13 & 13 & 44.5 & 43.7 \\
\hline ANXA5_RAT & ANXA5 & 411 & 265 & 10 & 10 & 37.3 & 43.6 \\
\hline ASSY_RAT & ASS1 & 71 & $1,030.1$ & 3 & 21 & 20.6 & 64.3 \\
\hline BHMT1_RAT & BHMT1 & 172.3 & 834.8 & 7 & 24 & 30 & 63.1 \\
\hline CALR_RAT & CARL & 277.1 & 607.2 & 8 & 13 & 31.7 & 49.5 \\
\hline CES1D_RAT & CESID & 598.6 & 571.1 & 15 & 16 & 38.8 & 50.8 \\
\hline DYH1_RAT & DNAHC1 & $1,391.9$ & $1,603.7$ & 77 & 89 & 23.5 & 27.7 \\
\hline EF2K_RAT & EEF2K & 354 & 304.5 & 18 & 17 & 38.5 & 34.1 \\
\hline ENPL_RAT & HSP90B1 & 742.6 & 492.2 & 25 & 16 & 29.6 & 23.5 \\
\hline EPHA6_RAT & EPHA6 & 486.4 & 361.4 & 27 & 20 & 32.4 & 24.5 \\
\hline FABPL_RAT & FABPL & 120.5 & 779.4 & 3 & 16 & 36.2 & 81.9 \\
\hline G3P_RAT & GAPDH & 486.7 & 763 & 14 & 18 & 53.8 & 62.2 \\
\hline OGA_RAT & MEGEA5 & 308.5 & 353.6 & 16 & 19 & 26.7 & 31.6 \\
\hline PARK7_RAT & PARK7 & 173.3 & 187.5 & 4 & 10 & 28.6 & 51.3 \\
\hline PRC2A_RAT & PRRC2A & 776.2 & 670.4 & 43 & 36 & 25.3 & 23.6 \\
\hline SI1L1_RAT & SI1L1 & 575.9 & 672.1 & 32 & 37 & 27.9 & 30.7 \\
\hline STIP1_RAT & STIP1 & 189.5 & 258.9 & 10 & 14 & 22.1 & 30 \\
\hline SYPM_RAT & PARS2 & 171.2 & 183.4 & 9 & 10 & 32.6 & 46.3 \\
\hline TBB4B_RAT & TUBB4B & 801.7 & 463.1 & 20 & 15 & 52.1 & 48.8 \\
\hline TPP1_RAT & TPP1 & 99.3 & 109.3 & 5 & 6 & 9.9 & 11.7 \\
\hline UBR4_RAT & UBR4 & $1,600.3$ & $1,813.1$ & 90 & 103 & 24.2 & 30.2 \\
\hline UD2B2_RAT & UGT2B & 390.2 & 705.3 & 21 & 25 & 44.7 & 59.1 \\
\hline
\end{tabular}

pattern of acetylation, described earlier as 'target proteins', and their respective peptides are described in Table 2, which provides target protein identification and their respective peptide scores in both groups as well as descriptions of the peptide acetylation positions.

Some peptides showed post-translational modifications, and these peptides are listed in Table 3. As expected, L-lysine appears to be the predominant acetylated amino acid in the peptide sequence, although arginine and histidine residues were found to be acetylated as well.

The acetylation ratio from target proteins ratio was calculated in order to more effectively visualize the increase in acetylation. The increase in acetylation can be clearly seen in Table 4, which shows the increase in the acetylation ratio in the peptides identified in both groups. The student's $t$-test was applied, and the difference was significant with $p<0.0001$, demonstrating that there was a significant increase of the acetylation in these peptides.

Analysis of the distribution of acetylated proteins within the subcellular localization revealed that they were predominantly located in the cellular membrane and cytoplasm $(53 \%)$. Nineteen percent are known to be present in the nucleus and $12 \%$ in the 
Table 3 Peptides from acetylated proteins in group treated with diacetyl but non-acetylated in control group.

Protein I.D. Gene I.D. Peptide sequence

\begin{tabular}{|c|c|c|c|c|c|}
\hline Protein I.D. & Gene I.D. & Peptide sequence & $\begin{array}{l}\text { Peptide } \\
\text { meta } \\
\text { score } \\
\text { control }\end{array}$ & $\begin{array}{l}\text { Peptide } \\
\text { meta } \\
\text { score } \\
\text { treated }\end{array}$ & $\begin{array}{l}\text { Acetylation } \\
\text { treated } \\
\text { group }\end{array}$ \\
\hline AL1A1_RAT & ALDH1A1 & -.MSSPAQPAVPAPLANLKIQHTK.I & 15.4 & 16.1 & $7 ; 20 ; 22$ \\
\hline ANXA2_RAT & ANXA2 & K.ELPSAMKSALSGHLETVMLGLLK.T & 15 & 21.7 & $3 ; 23$ \\
\hline ANXA2_RAT & ANXA2 & K.ELPSAMKSALSGHLETVMLGLLK.T & 15 & 16.6 & $3 ; 23$ \\
\hline ANXA2_RAT & ANXA2 & K.GVDEVTIVNILTNR.S & 71.9 & 18.2 & 14 \\
\hline ANXA2_RAT & ANXA2 & K.SALSGHLETVMLGLLK.T & 94 & 18.6 & 6 \\
\hline ANXA5_RAT & ANXA5 & K.YMTISGFQIEETIDRETSGNLENLLLAVVK.S & 16.4 & 16.7 & 15 \\
\hline ANXA5_RAT & ANXA5 & K.YMTISGFQIEETIDRETSGNLENLLLAVVK.S & 16.4 & 17.6 & $5 ; 30$ \\
\hline ASSY_RAT & ASS1 & R.GIYETPAGTILYHAHLDIEAFTMDR.E & 39.8 & 16.1 & $13 ; 5$ \\
\hline BHMT1_RAT & BHMT & R.IASGRPYNPSMSKPDAWGVTK.G & 16.3 & 17.5 & 5 \\
\hline BHMT1_RAT & BHMT & R.IASGRPYNPSMSKPDAWGVTK.G & 15.4 & 15.4 & $21 ; 30$ \\
\hline CALR_RAT & CALR & K.HEQNIDCGGGYVK.L & 33 & 85.7 & 13 \\
\hline CES1D_RAT & CES1D & K.GKVLGK.Y & 24.4 & 15.1 & 2 \\
\hline CES1D_RAT & CES1D & R.SHRDAGAPTFMYEFEYRPSFVSAMRPK.T & 18.5 & 22.7 & $2 ; 25$ \\
\hline CES1D_RAT & CES1D & R.SHRDAGAPTFMYEFEYRPSFVSAMRPK.T & 18.5 & 15.7 & $2 ; 7 ; 25$ \\
\hline DYH1_RAT & DNAH1 & R.SSLTRLASHMAEYECFQVELSK.N & 19 & 16.7 & 5 \\
\hline EF2K_RAT & EEF2K & R.SGDLYTQAAEAAMEAMK.G & 30.7 & 21.1 & 7 \\
\hline ENPL_RAT & HSP90B1 & R.MMKLIINSLYK.N & 18.8 & 16.1 & $1 ; 3$ \\
\hline EPHA6_RAT & EPHA6 & R.EASIMGQFDHPNIIRLEGVVTK.R & 18.3 & 16.8 & $0 ; 5$ \\
\hline EPHA6_RAT & EPHA6 & K.SVTEFNGDTITNTMTLGDIVYK.R & 28.2 & 50.8 & 22 \\
\hline FABPL_RAT & FABPL & K.SVTEFNGDTITNTMTLGDIVYK.R & 16 & 36.2 & 22 \\
\hline FABPL_RAT & FABPL & K.YQVQSQENFEPFMK.A & 28.2 & 33.9 & 4 \\
\hline G3P_RAT & GAPDH & K.RVIISAPSADAPMFVMGVNHEK.Y & 18.6 & 23.1 & $1 ; 20 ; 22$ \\
\hline G3P_RAT & GAPDH & K.RVIISAPSADAPMFVMGVNHEK.Y & 18.6 & 15.8 & $20 ; 22$ \\
\hline G3P_RAT & GAPDH & K.RVIISAPSADAPMFVMGVNHEK.Y & 18.6 & 15.8 & $20 ; 22$ \\
\hline G3P_RAT & GAPDH & K.RVIISAPSADAPMFVMGVNHEK.Y & 18.6 & 23.1 & $1 ; 20 ; 22$ \\
\hline OGA_RAT & MGEA5 & K.LDQVSQFGCRSFALLFDDIDHNMCAADK.E & 20 & 15.4 & $21 ; 28$ \\
\hline PARK7_RAT & PARK7 & K.GAEEMETVIPVDIMR & 28.2 & 16.1 & $5 ; 6$ \\
\hline PRC2A_RAT & PRRC2A & K.ALYPGALGRPPPMPPMNFDPRWMMIPPYVDPR.L & 17.9 & 30.3 & 9 \\
\hline PRC2A_RAT & PRRC2A & K.ALYPGALGRPPPMPPMNFDPRWMMIPPYVDPR.L & 17.9 & 18.9 & 9 \\
\hline PRC2A_RAT & PRRC2A & K.ALYPGALGRPPPMPPMNFDPRWMMIPPYVDPR.L & 17.9 & 16.6 & 21 \\
\hline PRC2A_RAT & PRRC2A & K.ALYPGALGRPPPMPPMNFDPRWMMIPPYVDPR.L & 17.9 & 26.6 & $21 ; 32$ \\
\hline PRC2A_RAT & PRRC2A & K.ALYPGALGRPPPMPPMNFDPRWMMIPPYVDPR.L & 17.9 & 19.4 & 32 \\
\hline PRC2A_RAT & PRRC2A & K.ALYPGALGRPPPMPPMNFDPRWMMIPPYVDPR.L & 17.9 & 15.1 & 9 \\
\hline PRC2A_RAT & PRRC2A & K.AVGTPGGNSGGAGPGISTMSRGDLSQR.A & 18.4 & 22 & $21 ; 27$ \\
\hline PRC2A_RAT & PRRC2A & R.ERSDSGGSSSEPFER.H & 17.1 & 15.4 & 15 \\
\hline SI1L1_RAT & SIPA1L1 & K.EKSKPYPGAELSSMGAIVWAVR.A & 15.6 & 19.4 & 2 \\
\hline SI1L1_RAT & SIPA1L1 & K.SLPLRRPSYTLGMK.S & 19.5 & 16.8 & 5 \\
\hline STIP1_RAT & STIP1 & R.RAMADPEVQQIMSDPAMR.L & 20.7 & 18.9 & $1 ; 8$ \\
\hline
\end{tabular}


Table 3 (continued)

Protein I.D. Gene I.D. Peptide sequence

\begin{tabular}{|c|c|c|c|c|c|}
\hline & & & $\begin{array}{l}\text { meta } \\
\text { score } \\
\text { control }\end{array}$ & $\begin{array}{l}\text { meta } \\
\text { score } \\
\text { treated }\end{array}$ & $\begin{array}{l}\text { treated } \\
\text { group }\end{array}$ \\
\hline STIP1_RAT & STIP1 & R.RAMADPEVQQIMSDPAMR.L & 20.7 & 20.4 & 8 \\
\hline SYPM_RAT & PARS2 & $\begin{array}{l}\text { K.GIEVGHTFYLGTKYSSIFNAHFTNA } \\
\text { HGESLLAEMGCYGLGVTR.I }\end{array}$ & 17.8 & 15 & $21 ; 26$ \\
\hline TBB4B_RAT & TUBB4B & R.INVYYNEATGGKYVPR.A & 21.9 & 15.4 & $6 ; 12$ \\
\hline TPP1_RAT & TPP1 & R.EREPELAQLLVDQIYENAMIAAGLVDDPR.A & 15.2 & 19.3 & 29 \\
\hline TPP1_RAT & TPP1 & R.INTLQAIWMMDPK.D & 15.9 & 15.1 & 3 \\
\hline UBR4_RAT & UBR4 & K.ALGTLGMTTNEKGQVVTK.T & 15.7 & 21.7 & 2 \\
\hline UBR4_RAT & UBR4 & K.EKAAPPPPPPPPPLESSPR.V & 18.3 & 18.1 & $2 ; 9$ \\
\hline UBR4_RAT & UBR4 & K.EKEGESSGSQEDQLCTALVNQLNR.F & 17.1 & 16.7 & $2 ; 24$ \\
\hline UBR4_RAT & UBR4 & K.FLSRPALPFILRLLR.G & 15.1 & 30 & $5 ; 12$ \\
\hline UBR4_RAT & UBR4 & R.DNPEATQQMNDLIIGKVSTALK.G & 28.8 & 17.2 & $6 ; 22$ \\
\hline UBR4_RAT & UBR4 & R.DNPEATQQMNDLIIGKVSTALK.G & 17.3 & 21 & 22 \\
\hline UBR4_RAT & UBR4 & R.MAGVMAQCGGLQCMLNRLAGVK.D & 19.3 & 23.9 & 7 \\
\hline UBR4_RAT & UBR4 & R.TGSTSSKEEDYESDAATIVQK.C & 19.4 & 17.3 & $7 ; 21$ \\
\hline UD2B2_RAT & UGT2B & K.EWDTFYSEILGRPTTVDETMSKVEIWLIR.S & 15.2 & 16.8 & $12 ; 22$ \\
\hline
\end{tabular}

cytoskeleton, while $14 \%$ are in different organelles, including mitochondria and endoplasmatic reticulum.

\section{Protein interaction analysis}

Figure 2 consists of the acetylated protein network from treated group. This network represents this protein interaction. Nodes represent the proteins in the network, and each color represents a different situation in relation to protein acetylation, while the edges represent the interactions between the proteins.

\section{Orthology analyses}

In order to reveal the involved cellular and metabolic processes as well as the subcellular location of the differentially expressed proteins in acetylation level with 2,3-butanedione treatment, the GO-based analysis was conducted.

Analysis of the Molecular Function (Fig. 3A) revealed catalytic activity (57\%), followed by specific binding function (19\%). The analyses of biological functions (Fig. 3B) indicated some processes in which acetylated proteins are involved, including cellular processes (28.6\%) and responses to stimulus (14.3\%). The top three protein classes (Fig. 3C) display hydrolase (19\%), chaperone (14.3\%) and oxidoreductase $(14.3 \%)$ activities. The cellular component analyses (Fig. 3D) demonstrated that acetylated proteins belong to macromolecular complexes (9.5\%), cell organelles (9.5\%), extracellular region (4.8\%) and other cell parts (19\%).

\section{Motif analysis of proteins containing arginine-, lysine- and histidine-acetylated peptides}

In order to characterize the possible specific sequence motifs surrounding acetylated arginine, lysine and histidine residues in peptides of lung samples, a logo sequence to 
Table 4 Ratio of acetylation in both groups: control and treated with 2,3-butanedione.

Protein I.D. Gene I.D. Peptide sequence

\section{AL1A1_RAT}

ANXA2_RAT

ANXA2_RAT

ANXA2_RAT

ANXA5_RAT

ASSY_RAT

BHMT1_RAT

CALR_RAT

CES1D_RAT

CES1D_RAT

DYH1_RAT

EF2K_RAT

ENPL_RAT

EPHA6_RAT

FABPL_RAT

FABPL_RAT

G3P_RAT

OGA_RAT

PARK7_RAT

PRC2A_RAT

PRC2A_RAT

PRC2A_RAT

SI1L1_RAT

SI1L1_RAT

STIP1_RAT

SYPM_RAT

TBB4B_RAT

TPP1_RAT

TPP1_RAT

UBR4_RAT

UBR4_RAT

UBR4_RAT

UBR4_RAT

UBR4_RAT

UBR4_RAT

UBR4_RAT

UD2B2_RAT

ALDH1A1

ANXA2

ANXA2

ANXA2

ANXA5

ASS1

BHMT

CALR

CES1D

CES1D

DNAH1

EEF2K

HSP90B1

EPHA6

FABPL

FABPL

GAPDH

MGEA5

PARK7

PRRC2A

PRRC2A

PRRC2A

SIPA1L1

SIPA1L1

STIP1

PARS2

TUBB4B

TPP1

TPP1

UBR4

UBR4

UBR4

UBR4

UBR4

UBR4

UBR4

UGT2B
-.MSSPAQPAVPAPLANLKIQHTK.I

K.ELPSAMKSALSGHLETVMLGLLK.T

K.GVDEVTIVNILTNR.S

K.SALSGHLETVMLGLLK.T

K.YMTISGFQIEETIDRETSGNLENLLLAVVK.S

R.GIYETPAGTILYHAHLDIEAFTMDR.E

R.IASGRPYNPSMSKPDAWGVTK.G

K.HEQNIDCGGGYVK.L

K.GKVLGK.Y

R.SHRDAGAPTFMYEFEYRPSFVSAMRPK.T

R.SSLTRLASHMAEYECFQVELSK.N

R.SGDLYTQAAEAAMEAMK.G

R.MMKLIINSLYK.N

R.EASIMGQFDHPNIIRLEGVVTK.R

K.SVTEFNGDTITNTMTLGDIVYK.R

K.YQVQSQENFEPFMK.A

K.RVIISAPSADAPMFVMGVNHEK.Y

K.LDQVSQFGCRSFALLFDDIDHNMCAADK.E

K.GAEEMETVIPVDIMR

K.ALYPGALGRPPPMPPMNFDPRWMMIPPYVDPR.L

K.AVGTPGGNSGGAGPGISTMSRGDLSQR.A

R.ERSDSGGSSSEPFER.H

K.EKSKPYPGAELSSMGAIVWAVR.A

K.SLPLRRPSYTLGMK.S

R.RAMADPEVQQIMSDPAMR.L

K.GIEVGHTFYLGTKYSSIFNAHFTNAH

GESLLAEMGCYGLGVTR.I

R.INVYYNEATGGKYVPR.A

R.EREPELAQLLVDQIYENAMIAAGLVDDPR.A

R.INTLQAIWMMDPK.D

K.ALGTLGMTTNEKGQVVTK.T

K.EKAAPPPPPPPPPLESSPR.V

K.EKEGESSGSQEDQLCTALVNQLNR.F

K.FLSRPALPFILRLLR.G

R.DNPEATQQMNDLIIGKVSTALK.G

R.MAGVMAQCGGLQCMLNRLAGVK.D

R.TGSTSSKEEDYESDAATIVQK.C

K.EWDTFYSEILGRPTTVDETMSKVEIWLIR.S
Acetylation

ratio control

group

0.5

0

0

0

0

0

0

0

0

0

2

0

0
0

0

\section{0}

0

0

0

\section{1}

\section{0}

1

\section{1}

0

\section{0}

0

\section{0}

\section{0}

\section{1}

\section{0}

$\begin{array}{ll}0 & 2\end{array}$

0

0

0

\section{0}

\section{1}

0

\section{2}

0

0
0
0

$\mathbf{0 . 2 8 3 7 8 3 7 8 4} \pm \mathbf{0 . 0 9 2}$ $(27)^{\mathrm{a}}$

1

1

1

1

1

1

1

1

2

1

1

1

1

2

1

1

1

2

1

2

2

3

1

2

1

Acetylation ratio treated group

0.666666667

2

2

1

1.5

2

2

1.5

2

0.5

0.5

2

\section{Mean}

Notes.

${ }^{\mathrm{a}}$ Mean \pm Std. Error $(\mathrm{N})$. 


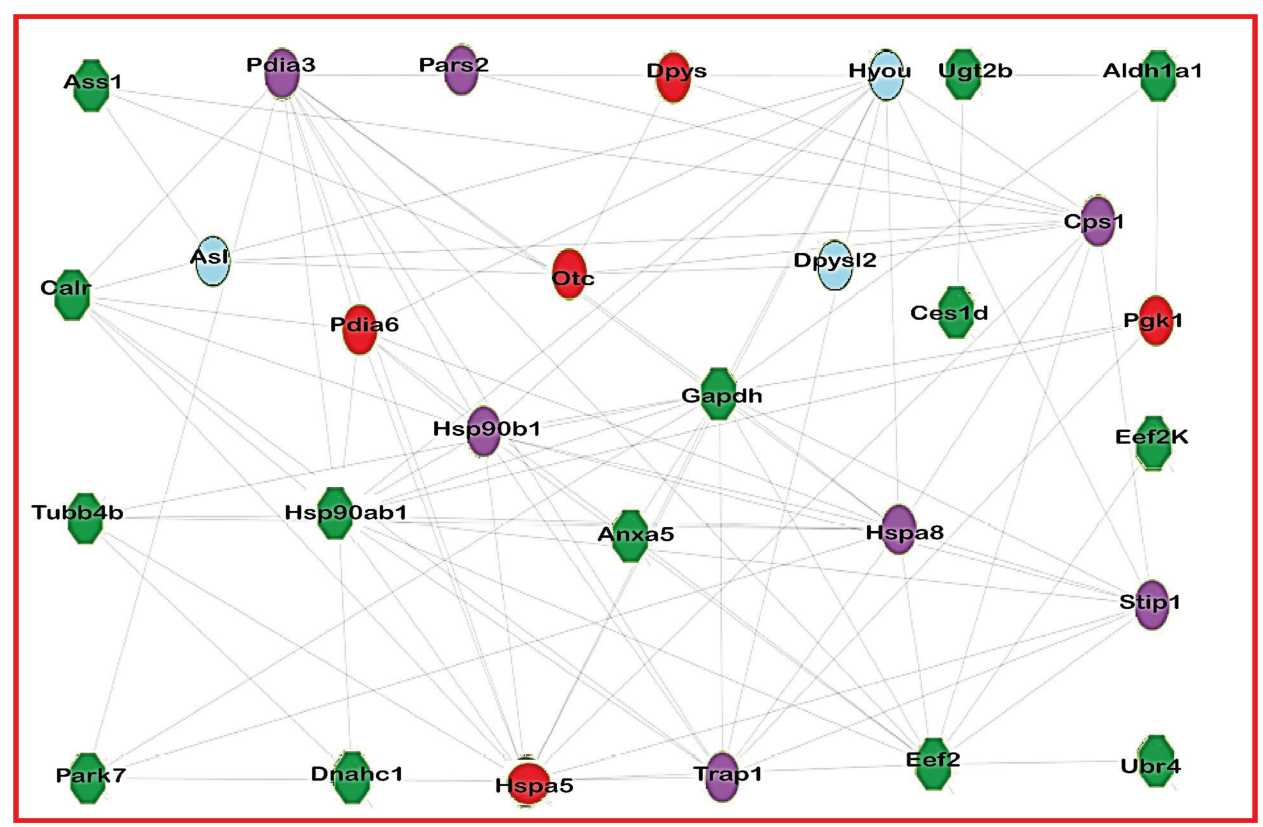

Figure 2 Network of acetylated proteins in group treated with Diacetyl. The green nodes are the proteins acetylated in group treated with Diacetyl but lack acetylation on treated groups. The red nodes are the proteins presents only in group treated with Diacetyl; the blue nodes are the proteins presents only in control group and the purple nodes are proteins present in both groups.

Full-size DOI: 10.7717/peerj.4688/fig-2

compute the likelihood of amino acids at the positions surrounding the acetylation site was generated. Ten significantly enriched motifs were obtained from all the identified acetylated sites including ${ }^{\star} \mathrm{K},{ }^{\star} \mathrm{R},{ }^{\star} \mathrm{H}\left({ }^{\star} \mathrm{K}\right.$ represents the acetylated lysine, ${ }^{\star} \mathrm{R}$ represents the acetylated arginine and ${ }^{\star} \mathrm{H}$ represents the acetylated histidine). As shown in Fig. 4, logos with the highest scores were used and all motif analyses are available in SM 2-7. Figures 4A and 4D show the motif surrounding acetylated arginine in samples from the control and treated groups, respectively, and Figs. 4B and 4E show the motif surrounding acetylated lysine. A number of reports have already demonstrated the occurrence of acetylation in arginine residue (Mathews et al., 2010). Figures 4C and 4F portray the motif surrounding acetylated histidine from control and groups treated with diacetyl, respectively.

\section{Western blotting}

Western blotting experiments indicated that the acetylation level was significantly higher in the treated group as compared to the control group (Fig. 5). Figure 5A shows an increase in acetylation in bands that correspond between $35-70 \mathrm{KDa}$ in lanes 5,7 and 8 that were filled with samples from the group treated with 2,3-butanedione. The wells filled with samples from the control group (lanes: 2-4) did not display the acetylation band.

Statistical analysis by the Student $t$-test revealed that mean values of protein intensities and variances are significantly different, with $p=0.0091$ for means and $p=0.0015$ for variance. This Western blotting experiment data confirms the result of LC-MS/MS 
A

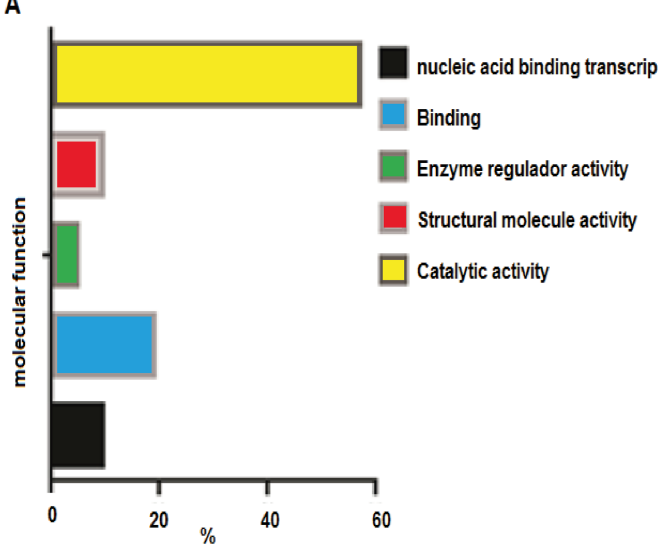

C

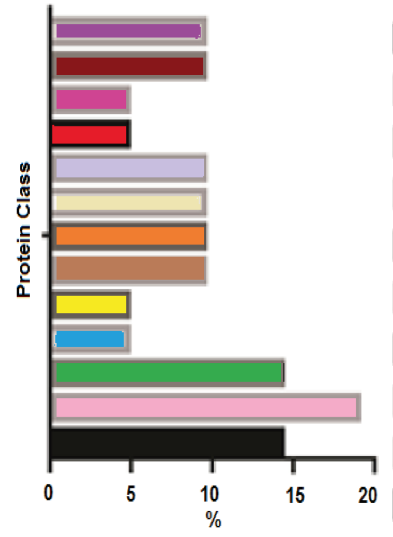

Chaperone

Hydrolase

Oxidoreductse

Enzyme modulator

Lyase

Transferase

Transcription factor

Nucleic acid binding

Ligase

Kinase

Calcium-binding protein

Cytoskeletal protein

Protease

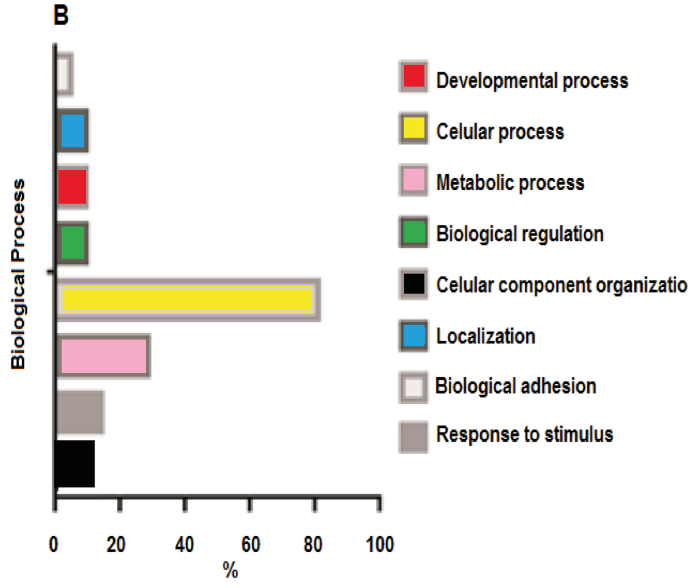

D

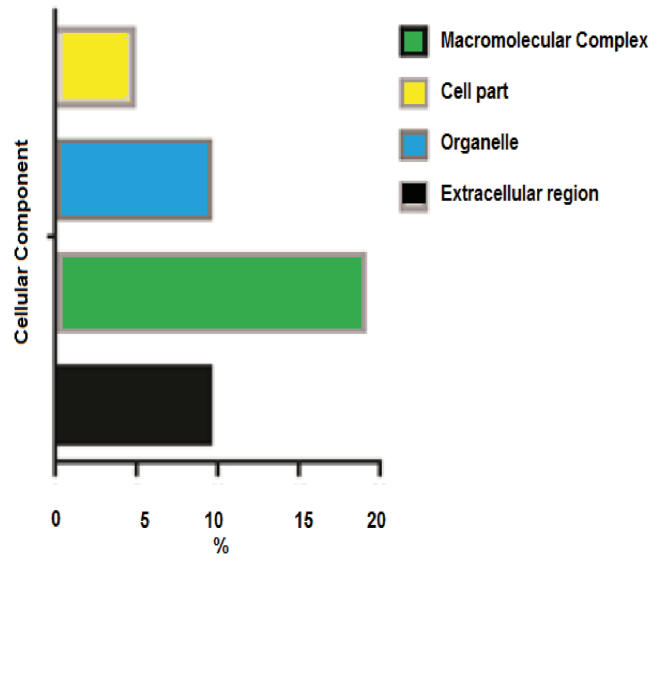

Figure 3 Orthology analyses from more acetylated proteins in group treated with Diacetil than in control group. (A) Molecular function; (B) biological process; (C) protein class; (D) cellular component.

Full-size DOI: 10.7717/peerj.4688/fig-3

analysis, which revealed increases in protein acetylation from the group treated with 2,3-butanedione in comparison with the control group.

\section{DISCUSSION}

\section{Protein extraction optimization}

The amount of proteins obtained from precipitated and resolubilizated proteins using three buffers. Buffers 1 and 2 were slightly more efficient than Buffer 3, which led us to choose Buffer 2 in all experiments. 
A
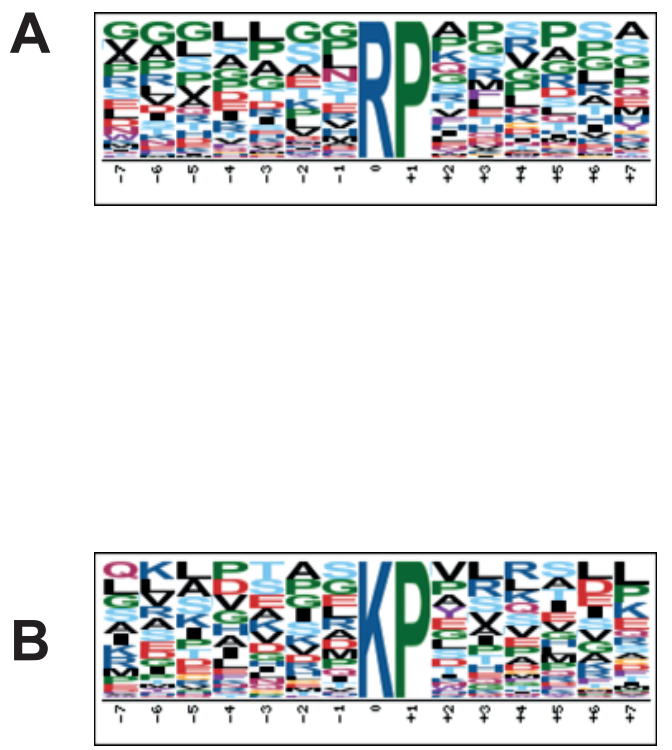

\section{D}

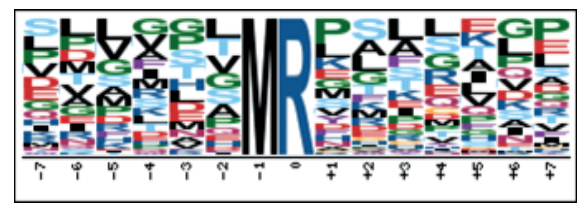

E

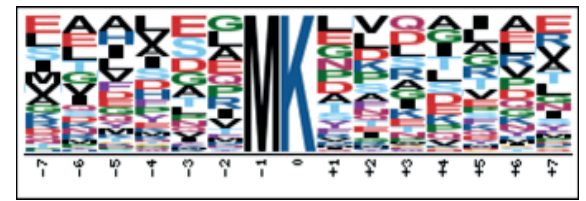

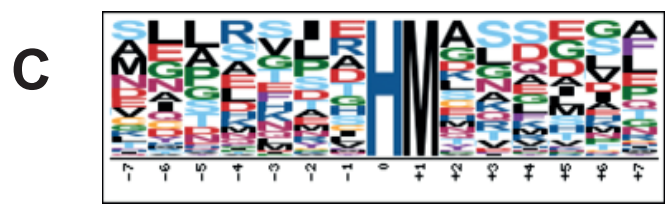

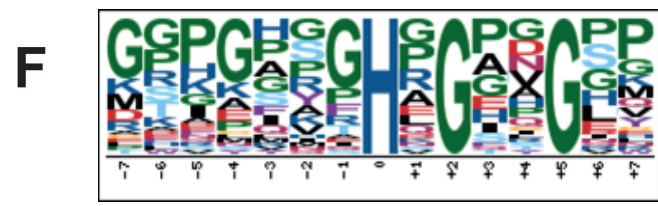

Figure 4 Motif analysis surrounding arginine, lysine and histidine acetylated peptides. (A) Motif analysis of control group, surrounding acetylated arginine. (B) Motif analysis of control group, surrounding acetylated lysine. (C) Motif analysis of control group, surrounding acetylated histidine. (D) Motif analysis of group treated with diacetyl, surrounding arginine. (E) Motif analysis of group treated with diacetyl, surrounding lysine. (F) Motif analysis of group treated with diacetyl, surrounding histidine.

Full-size DOI: 10.7717/peerj.4688/fig-4

\section{MS/MS analyses of rat lung proteins}

The results from provide evidence of an increase in protein acetylation in the group treated with diacetyl. Acetylation reportedly alters protein function, size, enzymatic activity, stability, protein-protein interactions and other protein properties. Some proteins regulate acetyltransferases and histone deacetylases and may induce acetylation of other proteins (Drazic et al., 2016). When acetyltransferases are deregulated, and lysine acetylation is increased, modifications may occur in genes and the regulatory machinery (Drazic et al., 2016). These data show that diacetyl- triggered protein acetylation takes place in different cell compartments and that it may be implicated in many cell functions. 
A

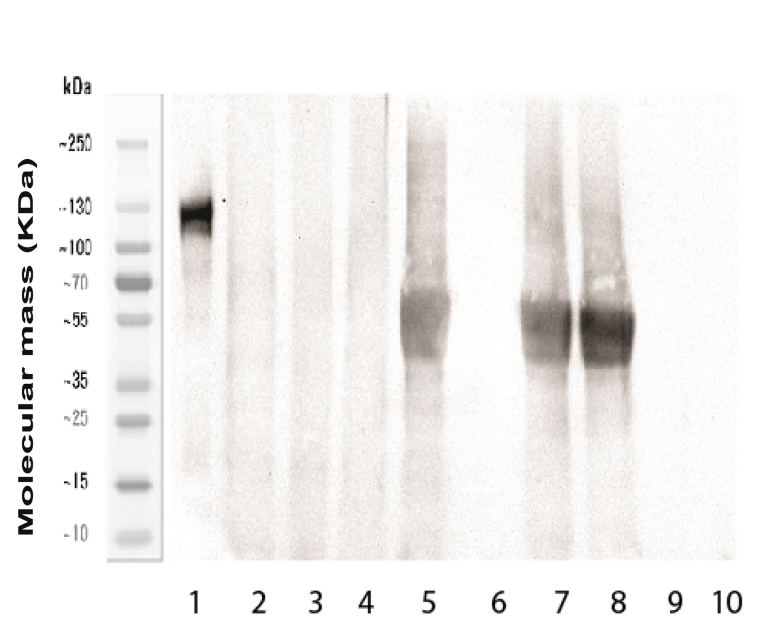

B

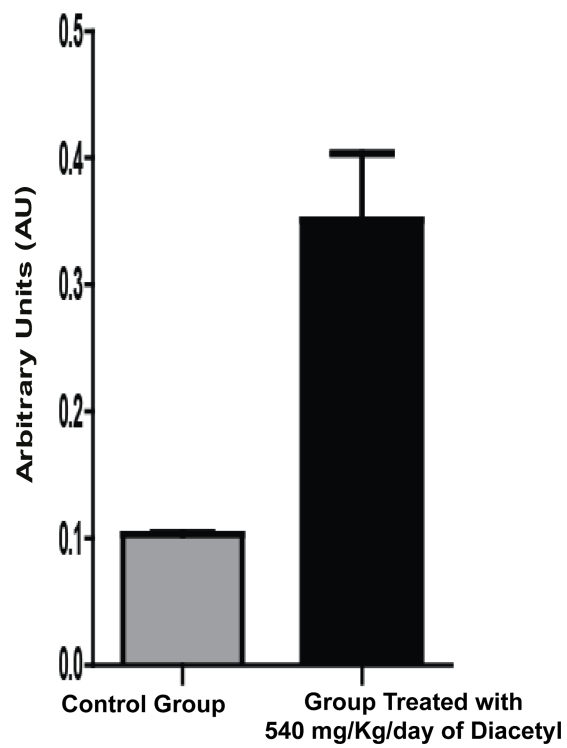

Figure 5 Western blotting for acetylated proteins from lung samples. (A) Western blotting 4 image: Lane 1: molecular weight; lanes 2-4: samples of the control group; lanes 5, 7, and 8: samples 5 of the diacetyl-treated group; and lanes 6, 9, and 10: sample buffer. (B) Western blotting quantification.

Full-size DOI: 10.7717 /peerj.4688/fig-5

\section{Protein interaction analysis}

The protein interaction analysis showed that some acetylated proteins are interconnected and/or connected with other proteins. To exemplify this interaction, we can cite the protein ASS1, found to be acetylated in the treated group, which interacts with both ALS and OTC. Present in our control group is the ALS enzyme, whose activity is regulated by acetylation, according to the UniProt database (http://www.uniprot.org). ASS1 interacts with OTC, which is present only in the diacetyl-treated group. OTC, one of the enzymes of the urea cycle, acts by detoxifying the excess of ammonium produced from amino acid catabolism and is negatively regulated by lysine acetylation (Yu et al., 2009).

Some acetylated proteins present in the network are involved in the cell redox balance (Drazic et al., 2016), in protein biosynthesis and have ATP and nucleotide binding activity, maturation, structural maintenance and regulation of specific proteins (Haase \& Fitze, 2016), along with cellular processes such as the basal metabolism, immunogenicity, cell cycle progression, DNA repair and apoptosis (Michalak et al., 2009). Some proteins also induce anti-tumor immunity by inhibiting angiogenesis and have antioxidant activity in neurons and the heart, protecting against cell death (Kolisek et al., 2015; Singh et al., 2015). Additionally, the proteins play a cytoprotective role being a redox-responsive protein (Eltoweissy et al., 2011).

The increase in chemical acetylation of lung proteins of diacetyl-treated rats described here may be connected with the fact that diacetyl has been shown in vitro to generate acetyl radicals upon reaction with peroxynitrite, and more slowly with hydrogen peroxide (Tokikawa et al., 2014). The diacetyl/peroxynitrite system was then reported to promote 
acetylation of isolated amino acids, peptides and albumin. These data led us to postulate that post-translational chemical acetylation of proteins may contribute to enzymatic acetylation at sites where both diacetyl and peroxynitrite at inflammation are formed.

\section{Orthology analyses}

The Gene Ontology (GO) function analysis of the target proteins revealed the distribution and function of these proteins. Protein acetylation regulates enzyme activities that mediate, for instance, the degradation of proteasomes and lysosomes by neutralizing the lysine residues in the active sites, thereby causing conformational changes. In addition to regulating the catalytic activity of metabolic enzymes, acetylation controls substrate accessibility, blocks substrate binding to the enzyme and modulates enzyme subcellular localization (Xiong \& Guan, 2012).

The most crucial pathways are those related to the oxidative stress response (P00046), which causes cellular damage. In a normal functioning cell, several transcription factors respond to oxidative stress by modulating the expression of genes whose products relieve the altered redox status.

\section{Motif analysis of proteins containing arginine-, lysine- and histidine-acetylated peptides}

The possible motifs surround acetylated arginine, lysine and histidine. Despite lysine being the more common site of protein acetylation, some studies have demonstrated that arginine can be acetylated as well, triggering biological responses (Rabbani et al., 2011; Slade, Subramanian \& Thompson, 2014). Acetylation in both lysine and histidine residue was previously demonstrated in vitro (Alves et al., 2013; Massari et al., 2010; Massari et al., 2011; Tokikawa et al., 2014), which reinforces our results about acetylation in these residues.

\section{Western blotting}

Western blotting was used to confirm the increase of acetylation previously found by NanoLc-ms/ms experiments. We used a specific acetylation antibody to detect bands with a substantial increase in intensity in samples from the group treated with diacetyl that reveals the protein acetylation increase. These results confirm the protein acetylation identified by NanoLc-ms/ms analyses.

\section{CONCLUSIONS}

Altogether, our data strongly suggest that diacetyl gavage administered to rats may constitute a source of acetyl radical that can attack and acetylate lung proteins. It is tempting to hypothesize that this is a contribution mechanism for the reported toxicity of diacetyl in workers dealing with 'buttered' food who subsequently acquire bronquiolitis obliterans.

Herein, we first optimized extraction conditions for the lung proteins of Wistar rats, for both rats in the control group and those treated with diacetyl. Mass spectrometry results, confirmed by Western blotting analyses, revealed increased acetylation in the lung tissues of groups treated with 2,3-butanedione. 
The proteins acetylated to different extents in the diacetyl-treated group were then related to reported interactions with other key proteins and enzymes of cell homeostasis. Diacetyl treatment, apparently, modifies the lung protein profile. Twenty-three diverse classes of proteins were found to undergo preferential acetylation. They are present in different regions of the cell and are involved in different molecular and biological processes. Our data indicate that the observed increased radical acetylation by diacetyl occurs randomly.

In a comprehensive view, we found more peptides acetylated in the group treated with diacetyl than in the control group. The expected acetylation of lysine residues also occurred in arginine and histidine, suggesting that unlike acetylase-driven acetylation of proteins, radical acetylation occurs randomly, modifying residues of both the N-terminal, the C-terminal and the side chain of basic amino acid residues. The Western blotting analysis clearly demonstrated increased protein acetylation due to the daily intake of diacetyl.

Our study is consistent with early in vitro studies that showed increases in protein acetylation in the presence of 2,3-butanedione. The data reported here reinforce our hypothesis that diacetyl exposure is capable of increasing protein acetylation in vivo, thus raising a potential for diacetyl, a highly electrophilic $\alpha$-dicarbonyl industrial xenobiotic, to play a role in inflammatory bronquiolitis obliterans (Cavalcanti et al., 2012; Cummings et al., 2014; Egilman \& Schilling, 2012).

\section{List of abbreviations}

$\begin{array}{ll}\text { ANXA2 } & \text { Annexin-A2 } \\ \text { ANXA5 } & \text { Annexin-A5 } \\ \text { ASS1 } & \text { Argininosuccinate synthase } \\ \text { BHMT1 } & \text { Betaine-homocysteine S-methyltransferase-1 } \\ \text { CALR } & \text { Calreticulin } \\ \text { CHAPS } & \text { 3-[(3-cholamidopropyl)dimethylammonio]-1-propanesulfonate } \\ \text { ES1D } & \text { Carboxylesterase-1D } \\ \text { DTT } & \text { Dithiothreitol } \\ \text { DNAH1 } & \text { Dynein heavy chain-1 } \\ \text { EF2K } & \text { Eukaryotic elongation factor-2 kinase } \\ \text { HSP90B1 } & \text { Endoplasmin } \\ \text { EPHA6 } & \text { Ephrin type-A receptor } \\ \text { FABPL } & \text { Fatty acid-binding protein } \\ \text { GAPDH } & \text { Glyceraldehyde-3-phosphate dehydrogenase } \\ \text { MGEA5 } & \text { O-GlcNAcase } \\ \text { PARK7 } & \text { Deglycase DJ-1 } \\ \text { PARS2 } & \text { Protein Probable proline-tRNA ligase PBS] Phosphate-buffered saline } \\ \text { PMSF } & \text { Phenylmethylsulfonyl fluoride } \\ \text { SIPA1L1 } & \text { Signal-induced proliferation-associated 1-like protein-1 } \\ \text { STIP1 } & \text { Stress-induced-phosphoprotein-1 } \\ \text { TUBB4B } & \text { Tubulin beta-4B chain } \\ \text { TFA } & \text { Trifluoroacetic acid } \\ \text { UBR4 } & \text { Ubiquitin-protein ligase } \\ \text { UGT2B } & \text { UDP-glucuronosyl- transferase-2B2. } \\ & \end{array}$




\section{ADDITIONAL INFORMATION AND DECLARATIONS}

\section{Funding}

This material is based upon work supported by the São Paulo Research Foundation (FAPESP, grants no. 2012/02514-9, 2013/07763-0, and 2010/01404-0) and the Brazilian Innovation Agency (FINEP). The funders had no role in study design, data collection and analysis, decision to publish, or preparation of the manuscript.

\section{Grant Disclosures}

The following grant information was disclosed by the authors:

São Paulo Research Foundation (FAPESP): 2012/02514-9, 2013/07763-0, 2010/01404-0.

Brazilian Innovation Agency (FINEP).

\section{Competing Interests}

The authors declare there are no competing interests

\section{Author Contributions}

- Leticia Dias Lima Jedlicka conceived and designed the experiments, performed the experiments, analyzed the data, prepared figures and/or tables, authored or reviewed drafts of the paper, approved the final draft.

- Sheila Barreto Guterres conceived and designed the experiments, performed the experiments, authored or reviewed drafts of the paper, approved the final draft.

- Aleksandro Martins Balbino and Giuseppe Bruno Neto performed the experiments, authored or reviewed drafts of the paper, approved the final draft.

- Richardt Gama Landgraf, Liliam Fernandes, Emanuel Carrilho and Etelvino José Henriques Bechara conceived and designed the experiments, analyzed the data, contributed reagents/materials/analysis tools, authored or reviewed drafts of the paper, approved the final draft.

- Nilson A. Assuncao conceived and designed the experiments, analyzed the data, contributed reagents/materials/analysis tools, prepared figures and/or tables, authored or reviewed drafts of the paper.

\section{Animal Ethics}

The following information was supplied relating to ethical approvals (i.e., approving body and any reference numbers):

This study was approved by the Ethical Committee of the School Medicine of the Federal University of São Paulo.

\section{Data Availability}

The following information was supplied regarding data availability:

Project Name: Wistar rat, lung, NanoLC-MS/MS

Project accession: PXD004504

https://www.ebi.ac.uk/pride/archive/projects/PXD004504. 


\section{Supplemental Information}

Supplemental information for this article can be found online at http://dx.doi.org/10.7717/ peerj.4688\#supplemental-information.

\section{REFERENCES}

Alves ANL, Jedlicka LDL, Massari J, Juliano MA, Bechara EJH, Assuncao NA. 2013. Electrospray ionization mass spectrometry applied to study the radical acetylation of amino acids, peptides and proteins. Journal of the Brazilian Chemical Society 24:1983-1990 DOI 10.5935/0103-5053.20130248.

Arif M, Selvi BR, Kundu TK. 2010. Lysine acetylation: the tale of a modification from transcription regulation to metabolism. ChemBioChem 11:1501-1504 DOI 10.1002/cbic.201000292.

Bradford MM. 1976. Rapid and sensitive method for quantitation of microgram quantities of protein utilizing principle of protein-dye binding. Analytical Biochemistry 72:248-254 DOI 10.1016/0003-2697(76)90527-3.

Cavalcanti ZDR, De Albuquerque Filho APL, Pereira CCA, Coletta AMEN. 2012. Bronchiolitis associated with exposure to artificial butter flavoring in workers at a cookie factory in Brazil. Jornal Brasileiro De Pneumologia 38:395-399 DOI 10.1590/S1806-37132012000300016.

Chou MF, Schwartz D. 2011. Biological sequence motif discovery using motif-x. Current Protocols in Bioinformatics 13:15-24 DOI 10.1002/0471250953.bi1315s35.

Colley J, Gaunt IF, Lansdown AB, Grasso P, Gangolli SD. 1969. Acute and shortterm toxicity of diacetyl in rats. Food and Cosmetics Toxicology 7(6):571-580 DOI 10.1016/S0015-6264(69)80460-8.

Cummings KJ, Boylstein RJ, Stanton ML, Piacitelli CA, Edwards NT, LeBouf RF, Kreiss K. 2014. Respiratory symptoms and lung function abnormalities related to work at a flavouring manufacturing facility. Occupational and Environmental Medicine 71:549-554 DOI 10.1136/oemed-2013-101927.

Drazic A, Myklebust LM, Ree R, Arnesen T. 2016. The world of protein acetylation. Biochimica et Biophysica Acta/General Subjects 1864(10):1372-1401 DOI 10.1016/j.bbapap.2016.06.007.

Egilman DS, Schilling JH. 2012. Bronchiolitis obliterans and consumer exposure to butter-flavored microwave popcorn: a case series. International Journal of Occupational and Environmental Health 18:29-42 DOI 10.1179/1077352512Z.0000000005.

Eltoweissy M, Muller GA, Bibi A, Phuc VN, Dihazi GH, Muller CA, Dihazi H. 2011. Proteomics analysis identifies PARK7 as an important player for renal cell resistance and survival under oxidative stress. Molecular BioSystems 7:1277-1288 DOI 10.1039/c0mb00116c.

Haase M, Fitze G. 2016. HSP90AB1: Helping the good and the bad. Gene 575:171-186 DOI 10.1016/j.gene.2015.08.063.

Iyer A, Fairlie DP, Brown L. 2012. Lysine acetylation in obesity, diabetes and metabolic disease. Immunology and Cell Biology 90:39-46 DOI 10.1038/icb.2011.99. 
Kanwal R, Kullman G, Fedan KB, Kreiss K. 2011. Occupational lung disease risk and exposure to butter-flavoring chemicals after implementation of controls at a microwave popcorn plant. Public Health Reports 126:480-494 DOI 10.1177/003335491112600405.

Kolisek M, Montezano AC, Sponder G, Anagnostopoulou A, Vormann J, Touyz RM, Aschenbach JR. 2015. PARK7/DJ-1 dysregulation by oxidative stress leads to magnesium deficiency: implications in degenerative and chronic diseases. Clinical Science 129:1143-1150 DOI 10.1042/CS20150355.

Kreiss K. 2014. Work-related spirometric restriction in flavoring manufacturing workers. American Journal of Industrial Medicine 57:129-137 DOI 10.1002/ajim.22282.

Kuhn ML, Zemaitaitis B, Hu LI, Sahu A, Sorensen D, Minasov G, Lima BP, Scholle M, Mrksich M, Anderson WF, Gibson BW, Schilling B, Wolfe AJ. 2014. Structural kinetic and proteomic characterization of acetyl phosphate-dependent bacterial protein acetylation. PLOS ONE 9(4):e94816 DOI 10.1371/journal.pone.0094816.

Massari J, Tokikawa R, Medinas DB, Angeli JPF, Di Mascio P, Assuncao NA, Bechara EJH. 2011. Generation of singlet oxygen by the glyoxal-peroxynitrite system. Journal of the American Chemical Society 133:20761-20768 DOI 10.1021/ja2051414.

Massari J, Tokikawa R, Zanolli L, Tavares MFM, Assuncao NA, Bechara EJH. 2010. Acetyl radical production by the methylglyoxal-peroxynitrite system: a possible route for l-lysine acetylation. Chemical Research in Toxicology 23:1762-1770 DOI 10.1021/tx1002244.

Mathews JM, Watson SL, Snyder RW, Burgess JP, Morgan DL. 2010. Reaction of the butter flavorant diacetyl (2,3-Butanedione) with $\mathrm{N}$-alpha-Acetylarginine: a model for epitope formation with pulmonary proteins in the etiology of obliterative bronchiolitis. Journal of Agricultural and Food Chemistry 58:12761-12768 DOI 10.1021/jf103251w.

McCoy MJ, Hoppe Parr KA, Anderson KE, Cornish J, Haapala M, Greivell J. 2017. Diacetyl and 2,3-pentanedione in breathing zone and area air during large-scale commercial coffee roasting, blending and grinding processes. Toxicology Reports 21(4):113-122 DOI 10.1016/j.toxrep.2017.01.004.

McEwan DG, Dikic I. 2011. The three musketeers of autophagy: phosphorylation, ubiquitylation and acetylation. Trends in Cell Biology 21:195-201 DOI 10.1016/j.tcb.2010.12.006.

Meng X, Lv Y, Mujahid H, Edelmann MJ, Zhao H, Peng X, Peng Z. 2018. Proteomewide lysine acetylation identification in developing rice (Oryza sativa) seeds and protein co-modification by acetylation, succinylation, ubiquitination, and phosphorylation. Biochimica et Biophysica Acta/General Subjects 1866(3):451-463 DOI 10.1016/j.bbapap.2017.12.001.

Mi H, Muruganujan A, Casagrande JT, Thomas PD. 2013. Large-scale gene function analysis with the PANTHER classification system. Nature Protocols 8:1551-1566 DOI 10.1038/nprot.2013.092. 
Michalak M, Groenendyk J, Szabo E, Gold LI, Opas M. 2009. Calreticulin, a multiprocess calcium-buffering chaperone of the endoplasmic reticulum. Biochemical Journal 417:651-666 DOI 10.1042/BJ20081847.

More SS, Raza A, Vince R. 2012. The butter flavorant, diacetyl, forms a covalent adduct with 2-deoxyguanosine, uncoils DNA, and leads to cell death. Journal of Agricultural and Food Chemistry 60:3311-3317 DOI 10.1021/jf300180e.

NIOSH. 1986. Hazard evaluation and technical assistance report. International Bakers Services, South Bend, 42. Available at https://www.cdc.gov/niosh/hhe/reports/pdfs/ 1985-0171-1710.pdf.

Papetti A, Mascherpa D, Gazzani G. 2014. Free alpha-dicarbonyl compounds in coffee, barley coffee and soy sauce and effects of in vitro digestion. Food Chemistry 164:259-265 DOI 10.1016/j.foodchem.2014.05.022.

Park RM, Gilbert SJ, Whittaker C. 2018. Pulmonary impairment and risk assessment in a diacetyl-exposed population: microwave popcorn workers. Journal of Occupational and Environmental Medicine Epub ahead of print Feb 132018 DOI 10.1097/JOM.0000000000001303.

Rabbani N, Godfrey L, Xue MZ, Shaheen F, Geoffrion M, Milne R, Thornalley PJ. 2011. Glycation of LDL by methylglyoxal increases arterial atherogenicity a possible contributor to increased risk of cardiovascular disease in diabetes. Diabetes 60:1973-1980 DOI 10.2337/db11-0085.

Ryan DA, Miller RM, Lee K, Neal SJ, Fagan KA, Sengupta P, Portman DS. 2014. Sex, age, and hunger regulate behavioral prioritization through dynamic modulation of chemoreceptor expression. Current Biology 24:2509-2517 DOI 10.1016/j.cub.2014.09.032.

Schwartz D, Gygi SP. 2005. An iterative statistical approach to the identification of protein phosphorylation motifs from large-scale data sets. Nature Biotechnology 23:1391-1398 DOI 10.1038/nbt1146.

Shannon P, Markiel A, Ozier O, Baliga NS, Wang JT, Ramage D, Amin N, Schwikowski B, Ideker T. 2003. Cytoscape: a software environment for integrated models of biomolecular interaction networks. Genome Research 13:2498-2504 DOI 10.1101/gr.1239303.

Shibamoto T. 2014. Diacetyl: occurrence, analysis, and toxicity. Journal of Agricultural and Food Chemistry 62:4048-4053 DOI 10.1021/jf500615u.

Singh Y, Chen H, Zhou Y, Föller M, Mak TW, Salker MS, Lang F. 2015. Differential effect of DJ-1/PARK7 on development of natural and induced regulatory T cells. Scientific Reports 5:17723 DOI 10.1038/srep17723.

Slade DJ, Subramanian V, Thompson PR. 2014. Citrulination unravels stem cells. Nature Chemical Biology 10:327-328 DOI 10.1038/nchembio.1504.

Szklarczyk D, Franceschini A, Kuhn M, Simonovic M, Roth A, Minguez P, Doerks T, Stark M, Muller J, Bork P, Jensen LJ, Von Mering C. 2011. The STRING database in 2011: functional interaction networks of proteins, globally integrated and scored. Nucleic Acids Research 39:D561-568 DOI 10.1093/nar/gkq973. 
Tokikawa R, Loffredo C, Uemi M, Machini MT, Bechara EJH. 2014. Radical acylation of L-lysine derivatives and L-lysine-containing peptides by peroxynitrite-treated diacetyl and methylglyoxal. Free Radical Research 48:357-370 DOI 10.3109/10715762.2013.871386.

Xiong Y, Guan KL. 2012. Mechanistic insights into the regulation of metabolic enzymes by acetylation. Journal of Cell Biology 198:155-164 DOI 10.1083/jcb.201202056.

Yu W, Lin Y, Yao J, Huang W, Lei Q, Xiong Y, Zhao S, Guan KL. 2009. Lysine 88 acetylation negatively regulates ornithine carbamoyltransferase activity in response to nutrient signals. Journal of Biological Chemistry 284:13669-13675 DOI 10.1074/jbc.M901921200. 